\title{
EFFECT OF TWO TYPES OF DIETARY GHEE ON SERUM LIPID LEVELS IN RATS
}

\author{
Karamaradi S. Nirmala1, Bhat Manjula S2, H. Sahajananda ${ }^{3}$
}

${ }^{1}$ Clinical Neurophysiology Technologist, Central Research Lab, Rajarajeswari Medical College and Hospital, Bengaluru.

${ }^{2}$ Research Assistant, Central Research Lab, Rajarajeswari Medical College and Hospital, Bengaluru.

3 Professor and HOD, Department of Anaesthesia Critical Care and Pain Medicine, I/C of Central Research Lab, Rajarajeswari Medical College and Hospital, Bengaluru.

\section{ABSTRACT}

Ghee is also known as clarified butter, utilized for thousands of years in Ayurveda as a therapeutic agent. Ghee which is known as "Gritha" in Ayurveda, described as the best among lipid media due to its quality of inheriting and enhancing the drug potency. Even though ghee is an animal fat, earlier studies have shown that larger doses given for cleansing purpose did not increase the level of Low Density Lipoprotein (LDL). Instead increased High Density Lipoprotein (HDL) or some time did not alter lipid profile at all. Earlier studies in rats, which were fed up to $10 \%$ dietary ghee showed dose dependent decrease in cholesterol and other lipid profiles. There are two methods in preparation of butter. One is from milk cream, clarified butter and the other from curds, cultured butter. Butter will be further processed to convert it into ghee. None of the earlier studies have shown, which type of ghee is better and compared their effects on lipid profiles. So, our objective of the study was to know the effects of $5 \%$ and $10 \%$ milk cream ghee (Ghee from clarified Butter) and curd ghee (Ghee made out of Cultured Butter) supplementation on lipid profile in Wistar rats. So we supplied 5\% and 10\% dietary ghee in a nutritionally balanced diet to 8 weeks old male rats for 12 weeks and estimated Total cholesterol, HDL, LDL, Very Low Density Lipoprotein (VLDL) and Triglycerides (TGL) levels after 12 weeks. These results indicate that $5 \%$ and $10 \%$ of cream ghee and $10 \%$ curds ghee did increase body weight after 12 weeks of consumption and $5 \%$ curds ghee was found not to increase the body weight; 5\% Curd Ghee has shown to lower total cholesterol, LDL, VLDL, triglycerides levels and cholesterol ratio more than other groups in our experimental model. HDL levels were increased in all the groups, which was not statistically significant in 5\% cream and $5 \%$ curd ghee groups.

\section{KEYWORDS}

Cream Ghee, Curd Ghee, Cholesterol, Lipids, Clarified Butter and Cultured Butter.

HOW TO CITE THIS ARTICLE: Nirmala KS, Manjula BS, Sahajananda H. Effect of two types of dietary ghee on serum lipid levels in rats. J. Evolution Med. Dent. Sci. 2016;5(49):3140-3144, DOI: 10.14260/jemds/2016/729

\section{INTRODUCTION}

Ghee commonly called "Gritha" in Sanskrit, has been utilized for thousands of years in Ayurveda as part of diet. According to Ayurveda, ghee promotes longevity and protects body from various diseases. ${ }^{1}$ It increases digestive fire and improves absorption and assimilation. It nourishes, ojas, the subtle essence of all the body tissues. It improves memory and strengthens the brain and nervous system. It lubricates the connective tissues, thereby rendering the body more flexible. In India ghee was used as a vehicle in many Ayurveda Medicinal preparations. Ghee cools the body and prevents overheat. Ghee makes internal body organs smooth and soft and also increases secretion of internal juices, which are diminished by aging.

Ghee improves intelligence and intellect. It also acts as a lubricant over the walls of GIT and facilitates easy egestion. Ghee is also better in wound healing. Ghee can be used as bath oil and also as moisturizer. Despite of these facts mentioned in Ayurveda and ancient Indian medical systems, public have an inhibition to consume ghee. Public believe that ghee raises serum cholesterol levels. Composition of ghee also supports their belief. Recently, many studies have proved that ghee is good for health. ${ }^{2}$ However, Ayurveda text Books mention two varieties of ghee based on processing methods.

Financial or Other, Competing Interest: None.

Submission 09-04-2016, Peer Review 16-05-2016,

Acceptance 21-05-2016, Published 18-06-2016.

Corresponding Author:

Dr. H. Sahajananda

413, $7^{\text {th }}$ Main, Vijaya Bank Colony,

Bannerghatta Road,

Bangalore-76.

E-mail: sahaj_anand@hotmail.com

DOI: 10.14260/jemds/2016/729
Mention of two types of butter is present in the popular Ayurvedic treatise Ashtanga Hrydayam - one is Ksheerodbhava - milk cream butter and the other is Dadhimadhonodbhava - curd butter. ${ }^{3}$ Further heating these two types of butter, we can procure cream and curd ghee respectively. But previously none of the studies mentioned these two varieties. According to Ayurveda, ghee is traditionally made in a way rather different than clarified butter. To make real ghee, one must obtain raw milk, then boil it, let it cool to $110^{\circ} \mathrm{F}\left(43^{\circ} \mathrm{C}\right)$, and add curd (Indian yogurt) cultures. After letting it set, covered at room temperature for around 12 hours, the curd is then churned using ancient methods to obtain this specific type of cultured butter. This butter is finally used to simmer into ghee.

So effort was made to study the effects of these two varieties, namely $5 \%$ and $10 \%$ ghee made out of cream and clarified butter and ghee made out of curd and cultured butter on serum cholesterol levels and lipid profile in rats.

\section{MATERIALS AND METHODS}

\section{Animals and Diets}

8 weeks old Male Wistar rats weighing about 200 grams were housed in polypropylene cages containing a bed of paddy husk. Rats were maintained at a temperature $22^{\circ} \mathrm{C}$ and $12: 12$ (dark: light) cycle. Animals were supplied with water and diet ad libitum. Study was conducted in Animal house and Central Research Laboratory, Rajarajeshwari Medical College, Bangalore. Animal care, treatment and anaesthesia were according to the guidelines of the Committee for Purpose of Control and Supervision of Experiments on Animals (CPCSEA). All experimental protocols were approved by the Institutional Animal Ethics Committee (IACE), Rajarajeshwari Medical College, Bangalore. The experimental diet comprised 
of chick pea $56.4 \%$, wheat $15 \%$, groundnut cake $10 \%$, Ghee obtained from milk cream and curd 5\% and 10\%, 6\% skimmed milk powder and $6 \%$ sugar.

\section{Study Design}

This was a comparative study. Overall, 25 numbers of male rats were used for the present study. They were randomly segregated into five groups (Five animals per group) as per the computer generated table. First animals group (G1) was control, which received the above-mentioned diet other than any other type of ghee content. Remaining four groups were experimental groups. Second (5\% cream ghee-G2) and third groups $(10 \%$ cream ghee - G3) were given ghee from milk cream and they were supplied with the above-mentioned diet with 5 and 10\% ghee obtained from milk cream respectively.

Fourth (5\% curd ghee - G4) and fifth $(10 \%$ curd ghee G5) group were ghee from curds and they were supplied with the above-mentioned diet with 5 and $10 \%$ ghee obtained from curdling of milk respectively. All five groups of rats were supplied with diet for twelve weeks. After twelve weeks, blood was collected from heart after starving them for 14 hours by cardiac puncture under ether anaesthesia. The serum cholesterol level and entire lipid profile was estimated. Body weight was measured before starting the experiment and once in a week till the experiment was completed. Percent gain in body weight was also calculated.

\section{Estimation of Cholesterol and Other Lipid Profiles}

Serum was separated from the blood and stored at $-20^{\circ} \mathrm{C}$ until estimation. Serum cholesterol, triglycerides, LDL, VLDL and HDL were estimated by using ERBA kit. Standard procedures were followed according to ERBA (Germany), samples were loaded to ERBA autoanalyser.

\section{Statistical Analysis}

Descriptive and inferential statistical analysis has been carried out in the present study. Results on continuous measurements are presented on Mean \pm SD (Min-Max) and results on categorical measurements are presented in Number (\%). Significance is assessed at 5\% level of significance. The following assumptions on data is made, Assumptions: 1. Dependent variables should be normally distributed, 2. Samples drawn from the population should be random, cases of the samples should be independent.

Analysis of Variance (ANOVA) has been used to find the significance of study parameters between three or more groups of patients, Post-Hoc Tukey Test has been used to find the significance of study parameters on continuous scale between two groups (Intergroup analysis) on metric parameters.

\section{Significant Figures \\ + Suggestive significance ( $\mathrm{P}$ value: $0.05<\mathrm{P}<0.10$ ) \\ * Moderately significant ( $\mathrm{P}$ value: $0.01<\mathrm{P} \leq 0.05$ ) \\ *** Strongly significant ( $\mathrm{P}$ value $: \mathrm{P} \leq 0.01$ )}

\section{Statistical Software}

The Statistical software namely SAS 9.2, SPSS 15.0, Stata 10.1, MedCalc 9.0.1, Systat 12.0 and $\mathrm{R}$ environment ver. 2.11.1 were used for the analysis of the data and Microsoft word and Excel have been used to generate graphs, tables, etc.

\section{RESULTS}

\section{Percent Gain in Body Weight}

After twelve weeks, percentage gain in body weight was significantly increased in all the groups except $5 \%$ curd ghee compared to the controls. (Table 1 and 2).

\section{Total Cholesterol Levels (mg/dL)}

After twelve weeks, all the ghee groups showed decreased cholesterol levels compared to controls which was statistically significant. It was more significant in the $5 \%$ and $10 \%$ curds ghee compared to controls. (Table 1 and 2).

\section{Cholesterol Ratio (Total Cholesterol Levels/HDL levels)}

There was decrease in cholesterol ratio between controls, and $5 \%$ \& $10 \%$ cream ghee and $5 \%$ and $10 \%$ curd ghee though it was statistically not significant. The cholesterol ratio is decreased more in $5 \%$ curd ghee compared to controls. (Table 1 and 2).

\section{HDL Levels (mg/dL)}

In all the groups HDL levels $(\mathrm{mg} / \mathrm{dL})$ was increased compared to controls. Increase in HDL in 5\% curds and 5\% cream ghee was not statistically significant. Significant change was seen in $10 \%$ curd ghee and $10 \%$ cream ghee compared to controls. (Table 1 and 2).

\section{LDL Levels (mg/dL)}

LDL levels (mg/dL) was decreased in $5 \%$ and $10 \%$ curd-ghee and $5 \%$ and $10 \%$ cream ghee compared to controls which was not statistically significant. (Table 1 and 2).

\section{VLDL Levels (mg/dL)}

VLDL Levels of $5 \%$ and $10 \%$ cream and curd ghee are decreased compared to control. There was no statistically significant change compared to controls. (Table 1 and 2).

\section{Triglycerides (TGL) levels (mg/dL)}

There was increase in triglycerides in $10 \%$ curd and cream ghee compared to control, though it was not significant. However, it was significantly decreased in the $5 \%$ cream ghee and $5 \%$ curd ghee. This decrease was more in $5 \%$ curd ghee. (Table 1 and 2).

\begin{tabular}{|c|c|c|c|c|c|c|}
\hline & Controls & 5\% Cream Ghee & 10\% Cream Ghee & 5\% Curd Ghee & 10\% Curd Ghee & P value \\
\hline Body weight & $67 \pm 1.58$ & $69.8 \pm 2.59$ & $71.4 \pm 1.14$ & $57.2 \pm 1.1$ & $73.2 \pm 0.84$ & $<0.001^{* *}$ \\
\hline Total cholesterol (mg/dL) & $45.2 \pm 1.92$ & $41.8 \pm 1.92$ & $41.4 \pm 2.3$ & $31.2 \pm 2.39$ & $39.4 \pm 1.52$ & $<0.001^{* *}$ \\
\hline HDL (mg/dL) & $11 \pm 1.58$ & $12.2 \pm 1.79$ & $15 \pm 2.24$ & $13.2 \pm 1.3$ & $14.6 \pm 2.07$ & $0.013^{*}$ \\
\hline LDL (mg/dL) & $23.8 \pm 1.48$ & $20.2 \pm 1.92$ & $21.4 \pm 1.82$ & $19.6 \pm 2.88$ & $21 \pm 3.39$ & 0.101 \\
\hline VLDL (mg/dL) & $13.6 \pm 2.7$ & $12 \pm 2.24$ & $11.4 \pm 2.41$ & $10 \pm 2.24$ & $13.2 \pm 1.92$ & 0.142 \\
\hline TGL (mg/dL) & $69.2 \pm 1.3$ & $63 \pm 4.47$ & $72.4 \pm 2.07$ & $60 \pm 2.83$ & $71.4 \pm 2.3$ & $<0.001^{* *}$ \\
\hline Total cholesterol/ratio & $\mathbf{4 . 1 \pm 1 . 4 8}$ & $\mathbf{3 . 4 \pm 1 . 6 7}$ & $\mathbf{2 . 8 \pm 0 . 8 4}$ & $\mathbf{2} \pm 1.22$ & $\mathbf{2 . 8} \pm 0.84$ & $\mathbf{0 . 1 1 7}$ \\
\hline \multicolumn{7}{|r|}{ Table 1: Comparison of Study Variables in Five Groups Studied } \\
\hline
\end{tabular}




\begin{tabular}{|c|c|c|c|c|c|c|c|c|c|c|}
\hline & $\begin{array}{c}\text { Controls- } \\
5 \% \\
\text { Cream } \\
\text { Ghee }\end{array}$ & $\begin{array}{c}\text { Controls- } \\
10 \% \\
\text { Cream } \\
\text { Ghee }\end{array}$ & $\begin{array}{l}\text { Controls- } \\
\text { 5\% Curd } \\
\text { Ghee }\end{array}$ & $\begin{array}{c}\text { Controls- } \\
10 \% \\
\text { Curd } \\
\text { Ghee }\end{array}$ & $\begin{array}{c}5 \% \\
\text { Cream } \\
\text { Ghee- } \\
10 \% \\
\text { Cream } \\
\text { Ghee }\end{array}$ & $\begin{array}{c}5 \% \\
\text { Cream } \\
\text { Ghee- } \\
\text { 5\% Curd } \\
\text { Ghee }\end{array}$ & $\begin{array}{c}5 \% \\
\text { Cream } \\
\text { Ghee- } \\
10 \% \\
\text { Curd } \\
\text { Ghee } \\
\end{array}$ & $\begin{array}{c}10 \% \\
\text { Cream } \\
\text { Ghee-5\% } \\
\text { Curd } \\
\text { Ghee }\end{array}$ & $\begin{array}{c}10 \% \\
\text { Cream } \\
\text { Ghee- } \\
10 \% \\
\text { Curd } \\
\text { Ghee }\end{array}$ & $\begin{array}{c}\text { 5\% Curd } \\
\text { Ghee- } \\
10 \% \\
\text { Curd } \\
\text { Ghee }\end{array}$ \\
\hline \multicolumn{11}{|l|}{ Difference } \\
\hline Body weight & 2.800 & 4.400 & 9.800 & 6.200 & 1.600 & 12.600 & 3.400 & 14.200 & 1.800 & 16.000 \\
\hline $\begin{array}{c}\text { Total cholesterol } \\
(\mathrm{mg} / \mathrm{dL})\end{array}$ & 3.400 & 3.800 & 14.000 & 5.800 & 0.400 & 10.600 & 2.400 & 10.200 & 2.000 & 8.200 \\
\hline HDL (mg/dL) & 1.200 & 4.000 & 2.200 & 3.600 & 2.800 & 1.000 & 2.400 & 1.800 & 0.400 & 1.400 \\
\hline LDL (mg/dL) & 3.600 & 2.400 & 4.200 & 2.800 & 1.200 & 0.600 & 0.800 & 1.800 & 0.400 & 1.400 \\
\hline VLDL (mg/dL) & 1.600 & 2.200 & 3.600 & 0.400 & 0.600 & 2.000 & 1.200 & 1.400 & 1.800 & 3.200 \\
\hline $\mathrm{TGL}(\mathrm{mg} / \mathrm{dL})$ & 6.200 & 3.200 & 9.200 & 2.200 & 9.400 & 3.000 & 8.400 & 12.400 & 1.000 & 11.400 \\
\hline $\begin{array}{c}\text { Total } \\
\text { cholesterol/ratio }\end{array}$ & 0.800 & 1.400 & 2.200 & 1.400 & 0.600 & 1.400 & 0.600 & 0.800 & 0.000 & 0.800 \\
\hline \multicolumn{11}{|l|}{ P value } \\
\hline Body weight & $0.072+$ & $0.002^{* *}$ & $<0.001^{*}$ & $<0.001^{*}$ & 0.510 & $<0.001^{* *}$ & $0.021^{*}$ & $<0.001^{*}$ & 0.397 & $<0.001^{* *}$ \\
\hline $\begin{array}{c}\text { Total cholesterol } \\
(\mathrm{mg} / \mathrm{dL})\end{array}$ & 0.100 & $0.054+$ & $<0.001^{* *}$ & $0.002^{* *}$ & 0.998 & $<0.001^{* *}$ & 0.367 & $<0.001^{* *}$ & 0.542 & $<0.001^{* *}$ \\
\hline HDL $(\mathrm{mg} / \mathrm{dL})$ & 0.835 & $0.019^{*}$ & 0.347 & $0.039^{*}$ & 0.150 & 0.906 & 0.268 & 0.540 & 0.997 & 0.745 \\
\hline LDL (mg/dL) & 0.167 & 0.529 & $0.080+$ & 0.381 & 0.931 & 0.994 & 0.984 & 0.761 & 0.999 & 0.886 \\
\hline VLDL $(\mathrm{mg} / \mathrm{dL})$ & 0.808 & 0.573 & 0.141 & 0.999 & 0.994 & 0.655 & 0.921 & 0.871 & 0.735 & 0.225 \\
\hline $\mathrm{TGL}(\mathrm{mg} / \mathrm{dL})$ & $0.017^{*}$ & 0.398 & $<0.001^{* *}$ & 0.728 & $<0.001^{* *}$ & 0.461 & $0.001^{* *}$ & $<0.001^{* *}$ & 0.979 & $<0.001^{* *}$ \\
\hline $\begin{array}{c}\text { Total } \\
\text { cholesterol/ } \\
\text { ratio } \\
\end{array}$ & 0.849 & 0.422 & $0.078+$ & 0.422 & 0.940 & 0.422 & 0.940 & 0.849 & 1.000 & 0.849 \\
\hline
\end{tabular}

\section{DISCUSSION}

There are a few studies done on animal models, which reveal the exact opposite effect of Ghee consumption on cholesterol levels. In an 8-week study done on Wistar rats that were fed a balanced diet including $2.5 \%$ to $10 \%$ Ghee, an inverse correlation was found between ghee consumption and cholesterol levels. ${ }^{4}$ In this paper, the serum lipid profiles of these animals showed a dose dependent decrease in total cholesterol, low-density lipoproteins and very low-density lipoproteins cholesterol and triglyceride levels when ghee was fed greater than $2.5 \%$ in the diet. Liver cholesterol and triglycerides also were decreased in these animals. In a related study by Kumar and his colleagues, two groups of rats fed an isocaloric diet containing Ghee or groundnut oil were compared to evaluate the cholesterol lowering effect of Ghee. In that study rats, which were fed ghee, had lower levels of cholesterol esters in the serum as well as in the intestinal mucosa. Native and oxidized ghee influenced cholesterol metabolism. They concluded that supplementation of diets with ghee would increase the excretion of bile constituents and lower serum cholesterol levels ${ }^{4}$.

In human trials, a study by Kumar MV. ${ }^{5}$ et al to know the effect of medicated ghee on serum lipid levels in psoriasis patients. They demonstrated hypolipidemic effects of ghee when given at high doses. In their study, patients were given daily incremental doses of $60 \mathrm{~mL}$ medicated ghee over a 7 day period. There was an $8.3 \%$ decrease in serum total cholesterol, a $26.6 \%$ decrease in serum triglycerides, a $17.8 \%$ decrease in serum phospholipids and a $15.8 \%$ decrease in serum cholesterol esters.

In another study. ${ }^{6}$ the authors compared the cancer protective effects of diet supplementation with Ghee Vs. Soybean oil on two groups of rats. They are of the opinion that Cow ghee compared to soybean oil, had a protective effect against carcinogen induced mammary cancer in rats. They are also of the opinion that dietary cow ghee compared to soybean oil down regulates the enzyme activities responsible for carcinogen activation in liver and up regulates carcinogen detoxification activities in liver and mammary tissues.

In another study on a rural population in one of the states in India revealed a significantly lower prevalence of CAD in men who consumed higher amounts of ghee. ${ }^{7}$

These studies provide evidence that dietary ghee up to $10 \%$ does not have any ill effects on serum lipids and may in fact be protective for diseases in outbred rats. In a study by Sharma et al in Sprague-Dawley outbred rats, results are consistent with the above findings. ${ }^{8}$ In another of their study in Fischer rats, an inbred strain that has been used as a model for genetic predisposition to diseases indicated that $10 \%$ dietary ghee did not have significant effects on serum total cholesterol levels when fed for 4 weeks, but raised total cholesterol levels when fed 8 weeks. ${ }^{8}$ Results showed an increase in serum triglyceride levels in Fischer rats fed with $10 \%$ dietary ghee for 4 weeks and for 8 weeks. However, $10 \%$ dietary ghee did not have any significant effect on liver microsomal lipid peroxidation and liver microsomal lipid peroxide levels. They are of the opinion that it is not likely to increase the risk of free radical induced diseases such as cardiovascular disease, neurodegenerative diseases and cancer. ${ }^{9}$

Is Ghee in spite of being a rich source of cholesterol and saturated fatty acids is good for the human beings? One theory suggests that its lipid peroxidation. ${ }^{10}$ that causes fat to become atherogenic (Plaque forming) and saturated fat is resistant to the oxidation process and hence cannot cause the formation of plaque. On the contrary, vegetable Polyunsaturated Fatty Acids (PUFA) are readily oxidized and PUFA-cholesterol esters are implicated in the process of plaque formation ${ }^{11}$ Another explanation suggests that Ghee is rich in Antioxidants including vitamin $A$, vitamin $E$ and carotenoids, which may be helpful in preventing lipid peroxidation. ${ }^{11}$

There are some controversies about how ghee consumption and serum lipid profile are linked. However, there is no correct scientific information in human subjects 
on this issue. In a study conducted on animal subjects in Iran, it has been observed that ghee oil consumption significantly increased HDL-C level, but did not have any significant effect on other serum lipids. ${ }^{11}$ Ghee was useful in modifying serum cholesterol including TG and HDL-C and liquid oil consumption along with frying oil resulted in a general reduction in serum lipids. They concluded by saying that ghee might be effective on serum lipids modification in metabolic syndrome. Ahmadiasl $\mathrm{N}$ et al also warned that it should not be forgotten that ghee, which is traditionally made from milk fat has high amounts of SFAs and its production method should be carefully supervised. Based on the positive effects of ghee oil on memory and prevention of cardiovascular disease, "we suggest to include ghee oil (even in small amounts) in the diet. 12 the advisable amount added to family diet requires" further investigations.

In another paper. 13 the author points out that Asian Indians previously had a low incidence of coronary heart disease and for generations had been using ghee in their cooking, which is low in PUFAs such as linoleic acid and arachidonic acid. The increased incidence of coronary heart disease in India began two to three decades ago when traditional fats were replaced by oils rich in linoleic and arachidonic acid as well as trans fatty acids, which comprises $40 \%$ of vanaspati. Wrong practice of adulteration of commercially prepared ghee with vanaspati is also wildly prevalent in India.

Thus, Ghee has shown to lower total cholesterol, LDL, VLDL and triglycerides in animal models. It also has shown to have a protective effect against mammary cancer proliferation. In human trials also, it has shown to decrease total cholesterol and triglycerides and reduce the prevalence of coronary artery disease. The ghee has also shown to improve the skin health in psoriasis patients.

However, none of the articles used ghee from two different sources. The process of creating traditional clarified butter is complete once the water is evaporated and the fat (Clarified butter) is separated from the solids in the milk. However, the production of ghee includes simmering the butter along with the milk solids so that they caramelize, which makes it nutty-tasting and aromatic.14-17 According to Ayurveda, ghee is traditionally made in a way rather different than clarified butter. It is said that to make real ghee, one must obtain raw milk, then boil it, let it cool to $110^{\circ} \mathrm{F}\left(43^{\circ} \mathrm{C}\right)$ and add curd (Indian yogurt) cultures. After that it should stay at room temperature for around 12 hours until it is set. The curd is then churned using ancient methods to obtain this specific type of cultured butter. This butter is finally used to simmer into ghee.

In our study (Table 1 and 2) after twelve weeks all the ghee groups showed decreased cholesterol levels compared to controls. It was more significant in the $5 \%$ curd ghee. There was significant change between controls and $5 \%$ and $10 \%$ cream ghee and $5 \%$ and $10 \%$ curd ghee. The cholesterol ratio is decreased more in 5\% curd ghee compared to controls. The lower the cholesterol ratio is better. According to the American Heart Association (AHA). ${ }^{18}$, one should aim to keep ratio below 5 with the ideal cholesterol ratio at 3.5. A cholesterol ratio of $5.0 \mathrm{mg} / \mathrm{dL}$ is considered as average risk in human beings. Above this value is high risk and below is less than average risk.
A ratio of $3.2 \mathrm{mg} / \mathrm{dL}$ or less is considered the optimal or the lowest risk. ${ }^{18-20}$ From our findings we can infer that longterm consumption of either cream or curd ghee does not increase the cholesterol ratio to above $5 \mathrm{mg} / \mathrm{dL}$ indicating no chance of even average risk. In all the groups, HDL levels (mg/dL) was increased compared to initial controls. Increase in HDL in 5\% curds and 5\% cream ghee was not statistically significant. Significant change was seen in $10 \%$ curd ghee and $10 \%$ cream ghee compared to controls.

Total cholesterol in fact is misleading and is a poor risk indicator, because it lumps together both LDL (bad) cholesterol and HDL (good) cholesterol. In our study, LDL levels $(\mathrm{mg} / \mathrm{dL})$ were decreased in $5 \%$ and $10 \%$ curd ghee and $5 \%$ and $10 \%$ cream ghee compared to controls. There was no significant change within the groups and also compared to controls. There is significant change in LDL level in 5\% curd ghee compared to controls. VLDL levels of $5 \%$ and $10 \%$ cream and curd ghee are decreased compared to control. It was decreased more in $5 \%$ curd ghee. There was no significant change within the groups and also compared to controls.

In our study, there was increase in triglycerides in $10 \%$ curd ghee and $10 \%$ cream ghee compared to control, though it was not significant. However, it was significantly decreased in the $5 \%$ cream ghee and $5 \%$ curd ghee. This decrease was more in $5 \%$ curd ghee. As per the above quoted studies.8,9 consumption of $10 \%$ dietary ghee increased triglycerides, but did not have any significant effect on liver microsomal lipid peroxidation and liver microsomal lipid peroxide levels. Hence, it is not likely to increase the risk of free radical induced diseases such as cardiovascular diseases, neurodegenerative diseases and cancer.

\section{CONCLUSION}

These positive research findings support the beneficial effects of two types of ghee outlined in the ancient Ayurveda system and the texts; $5 \%$ curd ghee was found to be better than the 5\% milk cream ghee; 5\% Curd Ghee has shown to lower total cholesterol, LDL, VLDL, triglycerides levels and cholesterol ratio in our experimental model. HDL levels were increased in all the groups, which were not significant except in $10 \%$ curd and $10 \%$ cream ghee groups. Large-scale further studies are required to confirm our findings.

\section{REFERENCES}

1. Lad V. The complete book of ayurvedic home remedies. Hormony books: The ayurveda encyclopedia, New York, 1998.

2. Kumar MV, Sambaiah K, Lokesh BR. Effect of dietary ghee-the anhydrous milk fat, on blood and liver lipids in rats. Nutr Biochem 1999;10(2):96-104.

3. Guptha KA. Two types of ghee Ashtanga hrdayam sutrasthnam. In: Edi Vaidya Yadunandan Upadhyaya, Editors. Chaukambha Sanskrit Sansthan 5 th chapter, 2006:p 44.

4. Kumar MV, Sambaiah K, Lokesh BR. Hypocholesterolemic effect of anhydrous milk fat ghee is mediated by increasing the secretion of biliary lipids. J Nutr Biochem 2000;11(2):69-75.

5. Kumar MV, Sambaiah K, Mangalgi SG, et al. Effect of medicated ghee on serum lipid levels in psoriasis patients. Indian J Dairy \& Biosci 1999;10:20-3. 
6. Rita Rani, Vinod K Kansal. Effects of cow ghee (clarified butter oil) \& soybean oil on carcinogen-metabolizing enzymes in rats. Indian J Med Res 2012;136(3):460-5.

7. Singh RB, Niaz MA, Ghosh S, et al. Association of trans fatty acids (vegetable ghee) and clarified butter (Indian ghee) intake with higher risk of coronary artery disease in rural and urban populations with low fat consumption. Int J Cardiol 1996;56(3):289-98.

8. Dwivedi C, Crosser AE, Mistry VV, et al. Effects of dietary ghee (clarified butter) on serum lipids in rats. J Appl Nutr 2002;52(2/3):65-8.

9. Hari Sharma, Xiaoying Zhang, Chandradhar Dwivedi. The effect of ghee (clarified butter) on serum lipid levels and microsomal lipid peroxidation. Ayu 2010;31(2):134-40.

10. Soelaiman IN, Merican Z, Mohamed J, et al. Serum lipids, lipid peroxidation and glutathione peroxidase activity in rats on long-term feeding with coconut oil or butterfat (ghee). Asia Pacific J Clin Nutr 1996;5(4):244-8.

11. Sserunjogi ML, Abrahamsen RK, Narvhus J. A review paper: current knowledge of ghee and related products. Int Dairy J 1998;8(8):677-88.

12. Ahmadiasl N, Alipour MR, Andalib S, et al. Effect of ghee oil on blood fat profile and passive avoidance learning in male rats. Medical Journal Tabriz University of Medical Sciences 2008;30(3):7-10.

13. Raheja BS. Dietary fats and habits and susceptibility of Asian Indians to NIDDM and atherosclerotic heart disease. J Diabet Assoc India 1991;31:21-8.
14. Spiteller G. The relation of lipid peroxidation processes with atherogenesis: a new theory on atherogenesis. Mol Nutr Food Res 2005;49(11):999-1013.

15. Iyer, Raghavan. 660 Curries, in the free encyclopedia. New York: Workman Publishing ISBN 978-0-7611-3787-0, 10 Jul 2013:p 21.

16. Jaffrey, Madhur. Madhur Jaffrey's Indian Cooking. London: BBC Books. ISBN 0-8120-6548-4, 1982:p 211.

17. Sahni, Julie. Julie Sahni's introduction to Indian cooking, under "usli ghee." Berkeley. Ten speed press. ISBN 089815-976-8, 1998:p 217.

18. American Heart Association. What your cholesterol levels mean 2013.

http://www.heart.Org/HEARTORG/Conditions/Cholester ol/AboutCholesterol/What-Your-Cholesterol-LevelsMean_UCM_305562_Article.jsp

19. Harvard Medical School. Understanding cholesterol tests 2005.

http://www.health.harvard.edu/fhg/updates/update020 5 c.shtml

20. 20. Lemieux I, Lamarche B, Couillard C, et al. Total cholesterol/HDL cholesterol ratio vs LDL cholesterol/HDL cholesterol ratio as indices of ischemic heart disease risk in men: the Quebec cardiovascular study. JAMA Internal Medicine 2001;161(22):2685-92. 